\title{
Understanding Japanese Tourists' Shopping Preferences \\ Using the Decision Tree Analysis Method
}

\author{
Samuel Seongseop Kim \\ College of Hospitality and Tourism \\ Sejong University, \\ 98 Gunja-Dong, Gwanjin-Gu, Seoul 143-747, Republic of Korea \\ sskim@sejong.ac.kr
}

Dallen J. Timothy

Tourism Development and Management, School of Community Resources and Development Arizona State University

411N. Central Avenue, Suite 550, Phoenix, Arizona 85004, USA

dtimothy@asu.edu

\author{
Jinsoo Hwang \\ Department of Hospitality Management and Dietetics \\ Kansas State University, USA \\ jinsoohwang@hanmail.net
}

This paper accepted for publication in Tourism Management, 20 April 2010. 


\title{
Understanding Japanese Tourists' Shopping Preferences \\ Using the Decision Tree Analysis Method
}

\begin{abstract}
This study was designed to assess the factors affecting Japanese tourists' shopping preference and intention to revisit Korea. The analytical method applied in this study was Decision Tree Analysis, which is under-utilized in tourism studies. A total of 300 questionnaires were collected on the basis of on-site survey method and used for data analysis. Among interesting findings, three groups including 'respondents who were satisfied, accompanied, and spent US\$50-300 on shopping', 'respondents who were satisfied, accompanied, and had a shopping expenditure of US\$300-1000' and 'respondents who were satisfied, accompanied, and had a shopping expenditure of US\$1000-5000,' showed a high level of intention to return to Korea for the purpose of shopping. In addition, two groups 'those who were interested in shopping in Korea, preferred a shopping mall as a shopping destination, and had an educational level of below high school' and 'those who were interested in shopping in Korea, preferred a shopping mall as a shopping destination, and had an educational level of a college graduate or above' showed a higher level interest in merchandise than in shopping venue attractiveness.
\end{abstract}

KEYWORDS: Shopping, Japanese tourists, Decision Tree Analysis, CHAID 


\section{Introduction}

Since the 1950s there have been many attempts to understand and model shopping, both as a utilitarian and leisure experience. The earliest works focused on shopping as an essential, or economic, activity that was necessary for everyday survival (Stephenson \& Willett, 1969; Stone, 1954). Later, researchers began entertaining the idea that shopping could be seen as a leisure pursuit, motivated more by enjoyment and pleasure than simply by economic necessity (e.g., Bellenger \& Korgaonkar, 1980; Bloch, Ridgway, \& Dawson, 1994; Finn, McQuity, \& Rigby, 1994; Lesser \& Hughes, 1986). As a clear extension of this leisure perspective, shopping's role in tourism both as a general leisure activity undertaken by tourists, as well as a primary motive for travel, has been the focus of considerable attention in the more recent tourism literature (e.g. Carmichael \& Smith, 2004; Coles, 2004; Heung \& Qu, 1998; Jansen-Verbeke, 1994; Law \& Au, 2000; Mok \& Lam, 1997; Moscardo, 2004; Timothy, 2005; Timothy \& Butler, 1995).

Among the most prominent issues under investigation currently in tourism studies that deal specifically with shopping and retailing are motivations, satisfaction, behaviours, shopper typologies, spatial travel patterns, the production and consumption of handicrafts and other souvenirs, purchase intensions, and authenticity of product and experience (Timothy, 2005). Numerous typologies have been created in recent years in an effort to understand the issues noted above, particularly the types of products tourists buy, their motives for shopping, and their behaviours/experiences in relation to shopping and purchasing products. In terms of product purchases, various taxonomies and other studies have concluded that people seek item authenticity, connections to the destination, utilitarian value, souvenirs' role as a reminder or memento of the trip, intrinsic beauty and workmanship, and relationships with craftspeople and 
vendors (Asplet \& Cooper, 2000; Littrell, 1990; Littrell et al., 1994; Onderwater, Richards, \& Stam, 2000).

From the perspective of behaviours and motivations, researchers have identified varying degrees of seriousness in relation to shopping, typically ranging from serious or passionate shoppers to casual visitors who buy little at all but browse or visit retail outlets as a way of using time (Littrell et al., 1994; Moscardo, 2004). Another line of inquiry has been the relationships between types of trips, or primary activities undertaken during travel, and type of shopping engaged in (Carmichael \& Smith, 2004; Oh, Cheng, Lehto, \& O'Leary, 2004). Often tourists are motivated to shop by a desire for keepsakes and tangible memories of an enjoyable holiday experience (Littrell, 1990; Timothy, 2005). Others shop because of the novelty a new environment creates, to fulfil functional needs, to purchase gifts for people at home, to use up excess time, to socialize and spend time with loved ones, to relax, or simply out of a sheer love of shopping in general (Anderson \& Littrell, 1995; Rowley \& Slack, 1999; Snepenger, 1987; Travel Industry Association of America, 2001), with underlying drivers being among others, prestige, economics, self-esteem or vanity (Butler, 1991). Studies have also confirmed that cultural background and other personal attributes, as well as social conditioning, influence the locations where people shop, their expectations and behaviours, and their product and activity preferences (Anderson \& Littrell, 1995; Kinley, Josiam, \& Kim, 2003; Littrell et al., 2004; Mok \& Lam, 1997; Prideaux \& Kim, 1999; Wong \& Law, 2003). Based upon this hypothesis, many studies have been undertaken with certain ethnic/national groups to examine whether or not ethnicity and nationality do in fact determine, or at least influence, shopping behaviour, product choice, and desired outcomes. By far the most commonly researched nationality in this respect is 
the Japanese, followed by Koreans and Chinese. East Asians demonstrate many similar cultural characteristics that are thought to influence their shopping behaviour while travelling.

\subsection{Study objectives}

This study's main purpose is to identify shopping behaviours and preferences of Japanese tourists who visit Korea. The total of inbound tourists to Korea since 2000 was recorded as $38,565,163$. The number of Japanese tourists to Korea among them was reported to be $16,194,884$, indicating about $42 \%$ of the Korean inbound tourism market. The number of arrivals of Japanese tourists was recorded at 1,802,542 in 2003, 2,443,070 in 2004 (a 35.5\% increase compared to the previous year), 2,440,139 in 2005, and 2,338,921 in 2006. The surge of Japanese arrivals in 2004 was due in part to the Hallyu phenomenon, which was boosted by broadcasts in Japan of the popular Korean TV drama series, Winter Sonata (KTO, 2004).

Regarding tourists' nationality, the Japanese market is the most dominating and thus is a substantially pivotal market to Korea's tourism industry. According to a report about expenditures by Japanese tourists (KTO, 2006), independent Japanese travelers spent US\$890 in Korea. The main expenditure source was shopping (US\$322, 36.2\%), followed by accommodations (US\$264, 29.7\%). Japanese group tourists spent an average US\$1128 per person in Korea, primarily on shopping (US\$398), which is the key expenditure category, aside from the cost of the tour (KTO, 2006). Thus, total expenditures by Japanese tourists in 2006 amounted to US $\$ 2.36$ billion by multiplying US\$1009 (average of expenditure by an individual tourist and a package tourist) by 2,338,921 (the number of Japanese tourists to Korea in 2006).

With regard to preferred products, $33.8 \%$ of Japanese tourists purchased kimchi, $63.2 \%$ purchased other food, and $16.7 \%$ bought cosmetics and perfume (KTO, 2006). The report 
indicates that the most preferred Japanese shopping venues were airport duty-free shops (42.5\%), department stores (30.4\%), and duty-free shops in Seoul City (28.7\%). Their main shopping destinations included Myongdong shopping district (74.2\%), Namdaemun market (65.1\%), and Dongdaemun market (45.3\%).

This study includes four specific objectives. First, it explores the literature related to shopping behaviours and preferences of Japanese tourists. An academic interest in Japanese tourists is attributed to the group being one of the most avid shopping nationalities (Foderaro,1998; Hobson, 2000; Hobson \& Christensen, 2001; Larke, 1994) and Japan being one of the biggest tourist-generating countries in the world. Second, this study attempts to apply the Decision Tree Analysis method to the field of tourism. Unfortunately, the use of this method has been limited to only a handful of previous studies (Chen, 2003; Chung, Oh, Kim, \& Han, 2004; Diaz-Perez, Bethencourt-Cejas, \& Alvarez-Gonzalez, 2005; Leones, Colby, \& Crandall, 1998; Rufin, 2007). Third, the study explores the effect of shopping tourists' characteristics, shopping travel patterns and shopping behaviour on further intention to return to Korea as shopping tourists. Fourth, it investigates the effect of shopping tourists' characteristics, travel patterns and consumer behaviour on factors considered important by tourists when deciding where to shop in Korea. The CHAID procedure depicted as a decision tree was used to actualize this analysis.

\section{Japanese shopping tourists' preferences and behaviours}

Japanese are among the most widely recognized groups of shopping tourists in the world. In fact, they appear to be more interested in shopping than other national or ethnic groups. Some studies show that American, Canadian, and European tourists are more interested in visiting cultural attractions, while the Japanese appear to be more interested in using their spare time to 
shop. For example, in Rosenbaum and Spears' (2005: 241) study, 59 percent of Japanese visitors to Hawaii planned to shop at designer boutiques, while only 35 and 34 percent of Americans and Canadians respectively planned to do so. The same study also found that 61 percent of US residents were interested in attending a luau cultural ceremony, while only 16 percent of Japanese respondents expressed interest in the same, because they preferred to use their time in retail venues. In support of these assertions, studies by Reisinger and Turner $(2000,2002)$ noted that shopping is one of the most significant variables that create tour satisfaction among Japanese travellers.

Japanese tourists are also high spenders. The state of Hawaii estimates that Japanese tourists spend approximately US\$90 per person per day, which is in most cases three times more than spending by visitors from Europe, Canada or the mainland United States (Rosenbaum \& Spears, 2005). A study by Jang, Bai, Hong and O’Leary (2004) found that Japanese tourists spent on average some US\$800 shopping during their trips to the United States, while an earlier study estimated that the most prosperous Japanese visitors spend some US $\$ 3000$ each trip; younger travellers usually spend around US\$1000 (Nishiyama, 1996). In short, Japanese tourists are among the world's biggest spenders when it comes to travel activities abroad, and this knowledge has led many destinations and retailers to promote themselves specifically to this national market segment (Foderaro, 1998; Hobson, 2000; Hobson \& Christensen, 2001; Larke, 1994).

Keown (1989) is one of the earliest tourism scholars to undertake a major study of Japanese shopping patterns. He found that approximately $80 \%$ of Japanese visitors to Hawaii spent more than five hours shopping and allocated $30 \%$ of their spending to themselves, and $60 \%$ to family, friends and work associates. Keown (1989) suggested that Japanese shopping at home 
is influenced by product availability, tax rates, relative value of products, and retailer strategies. These appear also to influence their shopping behaviour while away from home, especially as regards price and store reputation (Keown, 1989; Rosenbaum \& Spears, 2006), which is obvious from their preference to shop in duty-free stores (Rosenbaum \& Spears, 2005). There is also a pattern involved in their most preferred consumer products, with the most favoured being food, clothing, handbags, tobacco, alcohol, cosmetics, shoes, scarves and handkerchiefs, chocolate/candy, leather products, and souvenir crafts (Keown, 1989; Timothy, 2005).

Patterns of Japanese shopping abroad are shaped by a variety of socio-cultural traditions, social status, and individual roles in society. Timothy (2005: 87 ) assembled a list of nine highly significant and inter-related socio-cultural traditions and practices associated with the Japanese that affect their shopping behaviours and satisfaction levels. These include:

- desire for brand-name, high-quality products

- prestige and social status

- outward appearances are very important

- gift-giving traditions (e.g. senbetsu and omiyage)

- lack of individualism; individuals are only part of a larger social community

- limited fluency in foreign languages

- expectations of high-quality service

- the principle that loyalty should be abundantly rewarded

- predisposition to travel in cohesive groups with rigid schedules

Although all of these create a unique Japanese shopping experience that demands highquality merchandise, excellent service, and attractive packaging, the most important of these for 
driving Japanese people to shop are social status and gift-giving. Japanese travellers seek internationally known brand-name commodities because these display a level of prestige and sophistication, and denote social stature and good taste (Hobson \& Christensen, 2001). By purchasing high-quality and brand-name items overseas, an individual's rank in society is reconfirmed and reinforced, often via their own declarations and boastings.

Related to appearances and prestige is the highly significant practice of gift-giving: omiyage and senbetsu (Ahmed \& Krohn, 1992; Iverson, 1997; Jansen-Verbeke, 1994; Ko, 1999). Omiyage is the tradition of giving gifts to friends, relatives, neighbours, and coworkers after a trip. In most cases, the items given should be characteristic of the destination visited and should possess a high value. Often these omiyage presents are a response to gifts (senbetsu) given by the same people before the trip, to assist in making the trip more enjoyable or affordable.

This practice of gift-giving (in the form of money, cameras, travel clothes, etc.) before a trip and responsive souvenir-giving following a journey fosters harmonious relationships and demonstrates gratitude for the kindness of others. Omiyage represents many things, including confirmation that someone actually visited a specific country or region, a means of communicating, an indication of one's social status and good manners, and an easing of a guilty conscious for going away and having fun while loved ones and acquaintances stayed home (Park, 2000). A failure to counter give would be an infringement of the custom of shared gift-giving and would result in negative repercussions for close relations.

In sum, most literature on Japanese shopping has been classified into preferred shopping items or preferred shopping destinations (Hobson \& Christensen, 2001; Keown, 1989; Rosenbaum \& Spears, 2005; Timothy, 2005), cultural influences (Ahmed \& Krohn, 1992; Iverson, 1997; Jansen-Verbeke, 1994; Ko, 1999; Rosenbaum \& Spears, 2005), shopping patterns 
(Keown, 1989; Rosenbaum \& Spears, 2005, 2006), and expenditures (Foderaro,1998; Hobson, 2000;Hobson\& Christensen, 2001; Jang et al., 2004; Larke, 1994; Nishiyama, 1996; Park, 2000; Rosenbaum \& Spears, 2005). Unfortunately, previous studies have not considered multiple variables at once, and most studies were written as descriptive analyses. Thus this study was designed to take into consideration diverse variables in a model using a complicated multivariate analysis method, CHAID.

\section{Conceptualization of the study}

Fig. 1 shows the conceptual framework for this study. This paper attempts to identify intention to return to Korea for shopping tourism and factors that are considered important by tourists when deciding where to shop in Korea using shopping tourists' sociodemographic variables and shopping tour-pertaining variables. All variables used in this study were measured as type of categorical data with two or more categorical levels. Here, intention to return to Korea for shopping tourism and factors that are considered important by tourists when deciding where to shop in Korea are dependent variables. As independent variables, shopping tourists' sociodemographic variables and shopping tour-pertaining variables were selected to find a model that best accounts for each dependent variable. The conceptual model results in two hypotheses.

Hypothesis 1: Japanese shopping tourists' socio-demographic variables and shopping tour-related variables are likely to have an effect on intention to return to Korea for shopping tourism.

Hypothesis 2: Japanese shopping tourists' socio-demographic variables and shopping tour-related variables are likely to have an effect on factors that are important for tourists when deciding where to shop in Korea. 
Figure 1 here

\section{Methods}

\subsection{Measurement}

Items indicating factors that are considered important by tourists in deciding where to shop in Korea were selected from the Korean domestic tourism literature (KNTO, 2003; Lim, 2000; Park \& Lim, 1996; Yoon, 2000) and from the international tourism literature (Anderson \& Littrell, 1995; Hobson \& Christensen, 2001; Keown, 1989; Kinley et al., 2003; Littrell et al., 2004; Mok \& Lam, 1997; Prideaux \& Kim, 1999; Reisinger \& Turner, 2002; Rosenbaum \& Spears, 2006; Timothy, 2005; Wong \& Law, 2003). These items consisted of attributes that a shopping destination has and the quality of the merchandise on offer. Items relating to the quality of shopping products were "shopping products are trendy and fashionable," "shopping products are various," "design of shopping products is good," "prices of shopping products are reasonable," and "shopping products are trustworthy."

On the other hand, items that indicate infrastructure or services that shopping tourism destinations offer were "there are many shopping malls which are open until late at night," "the shopping destinations provide enjoyable events such as performances or concerts," "the shopping locations are well connected to other tourism destinations," and "shopping locations offer opportunities to meet other people.” The 11 items were measured by asking respondents to indicate their level of agreement (strongly disagree (1), neutral (4), and strongly agree (7)).

In addition, respondents' socio-demographic information (gender, education level, age, occupation, and monthly household income) and shopping travel-related information (frequency of visits to Korea, duration of tour, who they toured with, the purpose of this tour, main sources 
of shopping information, perceived inconvenience of shopping, amount spent shopping, preferred products for purchasing, and preferred place to shop) were measured as categorical variables.

\subsection{Study site}

On-site surveys were conducted at three popular shopping areas in Seoul: Myongdong shopping district, Dongdaemun market, and Namdaemun market. Japanese tourists tend to show a high preference for these three shopping areas, whereas Western tourists tend to prefer the Itaewon district (KNTO, 2003). The three places are must-see destinations for shopper tourists. The Myongdong district is particularly well known to Japanese tourists (KTO, 2006). Several reasons for shopping area preference explain this position: (1) there are hotels nearby where most Japanese tourists stay whilst in Seoul; (2) the district is known for its up-market shopping

products such as jewellery, famous designer brands, and high quality ceramic ware; (3) the place is full of many Japanese restaurants and bars; (4) the district is the hub of Korean economic activity, including banking and business or administrative offices; and (5) the district is close to the national museum, palaces, the railway station, and the airport.

Dongdaemun market is well known to young domestic and foreign tourists because the area has several modern buildings more than 30 stories high that are used for shopping arcades, malls, restaurants, and offices. Likewise, daily events such as performances and concerts by young dancers and singers are held on various stages throughout the market; the market stays open until 3 or 4 o'clock in the morning, particularly in the summer, meaning that tourists are able to enjoy the nightlife the area has to offer even after they return from an excursion; and the products sold in the market, including clothes, shoes, bags, jewellery, and sports gadgets, are 
relatively inexpensive but useful. Thus, Dongdaemun market is a bustling place, attracting many young and middle-aged people. It is particularly busy at peak times on Friday and Saturday.

Namdaemun market is famous for being a traditional Korean market. It is full of pavilions and tents that poorer merchants put up between low buildings. Compared to Myongdong shopping district and Dongdaemun market, the district is unclean, shabby, and old fashioned. Products sold to tourists in the market include clothes, Korean antiques, used goods, and used books. Customers of this market tend to be made up of those who like old-fashioned or used products, like to bargain with vendors, and like to see the social network of Korean vendors. Fig. 2 shows locations of the three shopping areas.

Figure 2 here

\subsection{Data collection}

As explained above, the three shopping districts are completely distinct. A total of 360 questionnaires were evenly distributed in the shopping district of Myongdong $(n=120)$, the shopping malls of Dongdaemun $(\mathrm{n}=120)$, and the Namdaemun market $(\mathrm{n}=120)$. Surveys were administered from September 26 to October 29, 2005, including three week days and two weekends. It was not difficult to collect the decided number of questionnaires from the three locations because the period was at the peak of the Japanese tourism season, due to mid-autumn festival holidays and pleasant fall weather. At the three sites, a convenience sampling method was used because it was not easy to control tourists' passage through these open sites. Interviewers were able to recognize Japanese tourists from their appearance and from hearing those who spoke Japanese. 
Only those who purchased or were planning to purchase products while in Korea were asked to fill in the questionnaire. Most Japanese tourists, except for those with an urgent travel itinerary, were willing to answer the questionnaire. It was presumed that one of the reasons why Japanese tourists had favourable attitudes toward completing the survey was the widespread popularity of the Korean TV drama series Winter Sonata, which is broadcasted in Japan (Brasor, 2004; Kim, Agrusa, Lee, \& Chon, 2007). Those who answered a questionnaire were given a small box of seasoned laver, a Korean dish popular with Japanese tourists. After excluding questionnaires that were either incomplete or had multiple missing data, a total of 300 questionnaires from the survey were used for further data analysis.

\subsection{Data analysis}

The major analytical concept used in this study is the Decision Tree Analysis. The approach is feasible through classifiers such as Chi-square Automatic Interaction Detection (CHAID), Automatic Interaction Detection, Classification and Regression Tree, Genetic Algorithm, and Artificial Neural Network. The selection of the classification algorithm rests on specific data characteristics and desired computation methods. On the one hand, the CHAID algorithm was first introduced in the 1970s by Kass (1975) and has been more actively applied in the field of consumer research (Haughton \& Oulabi, 1997; Levin \& Zahav, 2001; Magidson, 1994; Riquier, Luxton, \& Sharp, 1997). The statistical approach has been utilized to identify hotel preferences using customers' demographic variables (Chung et al., 2004), expenditure levels using tourists' demographic and travel pattern variables (Diaz-Perez et al., 2005), future recommendations using satisfaction with products, overpricing, and lacking assistance (Chen, 2003). 
The CHAID is a criterion-based approach that allows marketers to understand segments in relation to a dependent variable (criterion) having two or more categories according to the combination of independent variables (predictors) (Chen, 2003; Diaz-Perez et al., 2005). To undertake the CHAID procedure, a dependent variable (criterion) and key independent variables (predictors) were initially chosen. The number of categories of independent variables relies on whether or not the results of the chi-square test are significant.

However, the measurement categories of the independent variables should be two or more. After one dependent variable and a set of independent variables of interest are inputted, the Answer Tree 3.1 program which can be activated with SPSS automatically produces the best decision tree model on the basis of variations of likelihood-ratio chi-square values when each independent variable is used for building the tree. Here, the most significant independent variable with a dependent variable becomes the first node and the procedure of splitting the nodes stops when no significance between the dependent variable and the independent variable is found.

This study has two models to test. The dependent variables for the two models were behavioural intention to return to Korea for shopping tourism and factors that are important for tourists when deciding where to shop in Korea. The independent variables considered in this study were respondents' socio-demographic variables and their shopping tour-related variables. All variables used in this study were categorical measurements with two or more categorical levels. The stopping rules for two CHAID analyses were a maximum tree depth of 3, a minimum of 25 cases for a given node, and significance level for splitting of 0.05 .

\section{Results}




\subsection{Profile of respondents}

Table 1 shows respondents' socio-demographic and shopping characteristics. The majority of the respondents were male $(67.6 \%)$, in their $20 \mathrm{~s}(29.3 \%)$ or $30 \mathrm{~s}(35.2 \%)$, and had a university degree or higher (77.2\%). About half of the respondents were company employees $(48.3 \%)$, with the next most significant category being housewives (27.9\%). Regarding their monthly household income, the highest percentage of respondents earned between 400,001 and 500,000 yen $(26.2 \%)$. The respondents' frequency of visits to Korea showed that the majority had only visited once (52.4\%), with $38.6 \%$ of respondents having visited between two and four times, and $9.0 \%$ having visited five times or more. The majority of respondents indicated that the duration of the tour was either two nights $(39.7 \%)$ or three nights $(36.6 \%)$. The majority were accompanied either by friends $(53.4 \%)$ or by association members or company coworkers $(16.9 \%)$.

Respondents indicated that the main purpose of their tour was leisure (76.6\%), with $11.4 \%$ indicating they were only in Korea for shopping and $8.3 \%$ indicating that they were in Korea for other reasons. Respondents' main sources of shopping information included tourism information guidebooks (48.3\%), acquaintances (18.3\%), and the Internet (17.9\%). Respondents indicated that the main inconveniences perceived whilst shopping were the language barrier $(37.5 \%)$ and transportation $(21.0 \%)$. The majority estimated their shopping expenditure to be 20,000 yen or below $(30.9 \%)$ or 40,000 to 60,000 yen $(28.6 \%)$. The most preferred item to purchase was food (71.4\%), followed by duty-free products of foreign brands (16.9\%) and clothes $(11.7 \%)$. The most preferred shopping locations were traditional markets $(51.7 \%)$, followed by duty-free shops (20.7\%) and shopping malls (19.3\%). 
Table 1 here

\subsection{Factor analysis of factors that are considered important by tourists when deciding where to shop in Korea}

To examine the dimensions underlying the instrument of factors that are considered important by tourists when deciding where to shop in Korea, a principal component factor analysis with varimax rotation was implemented. The 11 items produced two factors with eigenvalues greater than 1.0. The items had factor loadings of over 0.42 and commonalities of over 0.45 . The factor structure accounted for $58.5 \%$ of the variance. Items consisting of the factor structure were consistently grouped into two domains, as suggested in a stage of instrument development.

Thus, the factors were termed "quality of shopping products" and "attractiveness of shopping destination." The first domain included items such as "shopping products are trendy and fashionable," "shopping products are various," "the design of shopping products is good," "prices of shopping products are reasonable," and "shopping products are trustworthy." The second domain included items such as "there are many shopping malls which are open until late at night," "the shopping destinations provide enjoyable events such as performances and concerts," "the shopping locations are well connected to other tourism destinations," and "shopping locations offer opportunities to meet many other people." The reliability alphas on the two domains were .82 and .74 , respectively.

\subsection{Results of identifying intention to return to Korea for shopping tourism}

Fig. 3 shows the results of the CHAID procedure. The dependent variable was "intention to return to Korea for shopping tourism" and the three descriptors splitting the nodes were 
"satisfaction level," "accompanied types," and "shopping expenditure." Among the respondents $(\mathrm{n}=290$ ), $6.90 \%$ indicated no intention to return to Korea for shopping, whereas $72.8 \%$ of them responded with an intention to return for shopping. The first splitting variable was "satisfaction level" $\left(\chi^{2}=84.95\right.$, d.f. $\left.=4 ; p=.000\right)$. In Node $3,94.7 \%$ of the respondents who indicated a high satisfaction level for shopping showed a high level of intention to return to Korea for shopping tourism. In addition, those who indicated a satisfactory shopping experience showed a very low percentage of negative intention to return.

The second pruning tree was based on the variable of "accompanied type" $\left(\chi^{2}=36.75\right.$, d.f. $=2 ; \mathrm{p}=.000$ ). Node 3 was diverged into Node 4 and Node 5 . About $95.9 \%$ of those who were satisfied with their shopping experience and were accompanied by others (Node 4) revealed a very high level of intention to return. On the other hand, $50 \%$ of those who were satisfied with their shopping experience and visited alone (Node 5) reported no desire to return.

The last split was "shopping expenditure" $\left(\chi^{2}=11.43\right.$, d.f. $\left.=4 ; \mathrm{p}=.022\right)$. Node $4(\mathrm{n}=$ 149) was pruned into Node $6(n=52)$, Node $7(n=62)$, and Node $8(n=33)$. About $88.5 \%$ of respondents who were satisfied with their shopping tourism visit, were accompanied by others, and spent US\$50-300 on shopping (Node 6) showed a high level of intention to return. Additionally, all respondents who were satisfied with their shopping tourism, were accompanied by others, and had an expenditure of US $\$ 300$ or more (Nodes 7 and 8) showed a high level of intention to return to Korea.

Figure 3 here 
Fig. 4 shows a risk chart indicating the preciseness of classification. It is similar to the percentage of classified respondents in the discriminant analysis. The risk estimate predicted the risk incurred due to misclassification of the respondents in the CHAID procedure. The less the estimate, the more precisely classified was the model. With regard to the results of assessing the respondents' intention of returning to Korea for shopping tourism, the risk estimate was 0.272414 . This means that the preciseness of classifying respondents was $72.8 \%$. That is, about $72.8 \%$ of the respondents were classified accurately on split nodes.

Figure 4 here

The gain chart shows information regarding the gain index score (Fig. 5). Identifying the gain index score was very helpful for understanding more precise characteristics of nodes that could be target segments (Chen, 2003). The gain index score is calculated by dividing the percentage of cases with a node (Gain N (\%) in Fig. 5) by the percentage of cases within the total number of respondents (N (\%) in Fig. 5). For example, Node 7 shows a gain index score of 137.4. The statistic came from dividing 29.4 (dividing 62 by 211 . Here, 211 indicates the number of those who indicated a high level of intention to return) by 21.4 (dividing 62 by 290 . Here, 290 indicates the total number of samples). Thus, the percentage of respondents belonging to Node 7 was $137.4 \%$, which is higher than the percentage of all samples, indicating a high level of intention to return.

Thus, nodes that had a gain index of over 100 were considered to be segments showing a higher percentage of respondents with a higher intention to return to Korea for shopping. In this study, the gain scores of Node 7 (respondents who were satisfied, accompanied, and spent 
US\$50-300 on shopping), Node 8 (respondents who were satisfied, accompanied, and had a shopping expenditure of US\$300-1000), and Node 6 (respondents who were satisfied, accompanied, and had a shopping expenditure of US\$1000-5000) were greater than 100. In conclusion, these groups could be the target markets of Japanese shopping tourists because the tourists in these segments indicated a higher level of intention to return to Korea for the purpose of shopping tourism when compared to the other segments.

Figure 5 here

\subsection{Results of identifying factors considered important by tourists when deciding where to shop in Korea}

The results of the CHAID procedure to identify factors which are considered important by tourists when deciding where to shop in Korea are shown in Fig. 6 . The dependent variable was "factors which are considered important by tourists when deciding where to shop in Korea," with three descriptors, namely "interest in shopping on this trip," "preferred shopping place," and "education level." Approximately $65.4 \%$ of the respondents indicated that they considered quality of shopping products important in deciding where to shop in Korea, while $34.6 \%$ of them showed that they considered that the attraction of the shopping tourism destination was more important than the quality of the shopping products.

The first pruning descriptor was attributed to "interest in shopping on this trip" $\left(\chi^{2}=\right.$ 10.37, d.f. $=2 ; \mathrm{p}=.006$ ). About $70.0 \%$ of the respondents indicated a high level of interest in shopping on this tour, whereas $2.8 \%$ of them showed a low level of interest. About $71.2 \%$ of 
those who indicated a high level of interest in shopping on this tour indicated that the quality of shopping products was more important than the attractiveness of the shopping destination.

The second split was based on the variable "shopping places" $\left(\chi^{2}=6.19\right.$, d.f. $=2 ; p$ $=.046$ ). Node 3 was pruned into three groups: Node 4 , Node 5 , and Node 6 . About $78.6 \%$ of respondents (Node 4) who had an interest in shopping and preferred visiting a traditional Korean market showed they considered the quality of shopping products to be more important than shopping destination-related attributes. In particular, compared to respondents who preferred the location for shopping tourism to be either a traditional Korean market or a duty-free shop, those respondents who showed a preference for a shopping mall as a shopping tourism destination tended to place importance on the quality of shopping products rather than on the shopping location's attractiveness.

The third split was "education level" $\left(\chi^{2}=10.64\right.$, d.f. $\left.=2 ; p=.005\right)$. In Node 7 , about $83.3 \%$ of those who were interested in shopping in Korea, preferred a shopping mall as a shopping destination, and had an educational level of a high school graduate or below indicated that the attractiveness of a shopping destination was more important than the quality of shopping products (Node 7). In contrast, all respondents who were interested in shopping in Korea, preferred a shopping mall as a shopping destination, and were college students tended to consider the quality of shopping products as being more important than the attractiveness of the shopping destination (Node 8).

Figure 6 here 
According to the results of the assessment of factors that are considered important by tourists when deciding where to shop in Korea, the risk estimate was 0.310954 (Fig. 7). This means that the preciseness of classifying respondents was $68.9 \%$. That is, about $68.9 \%$ of the respondents were classified accurately on split nodes.

\section{Figure 7 here}

Fig. 8 presents a gain chart of those who considered the quality of shopping products as being more important than the attractiveness of a shopping destination when deciding where to shop in Korea. As mentioned above, nodes that had a gain index of over 100 were regarded as segments which included a higher percentage of respondents with a higher intention to return to Korea for shopping. In Fig. 8, Node 8 (those who were interested in shopping in Korea, preferred a shopping mall as a shopping destination, and had an educational level of college students) and Node 9 (those who were interested in shopping in Korea, preferred a shopping mall as a shopping destination, and had an educational level of a college graduate or above) had gain indexes greater than 100. The results, therefore, provide important information on target markets, revealing those groups who think that shopping products are more important than a shopping destination's attractiveness.

Figure 8 here

\section{Conclusion and discussion}


Since Japanese tourists comprise some $41.2 \%$ of the Korean inbound market, the group's importance is substantial. Of their total trip costs, Japanese tourists spent $36.2 \%$ on shopping. Given this important position, this study aimed to predict intention to return to Korea for shopping purposes and elucidate factors that are important for tourists when deciding where to shop in Korea by examining respondents' socio-demographic and shopping-related variables.

Results of the CHAID analyses indicated contributing factors to predicting intention to return to Korea for shopping and important factors for tourists when deciding where to shop in Korea. Several findings have significant implications for marketing and destination management. First, three significant independent variables splitting nodes (satisfaction level, companionship types, and shopping expenditure) were useful in predicting intention to return to Korea to shop. As Fig. 3 shows, approximately $73 \%$ of respondents intended to return to Korea to shop. Some $95 \%$ of the 'satisfied' respondents indicated an intention to return. This corresponds well to findings published in the annual reports of the Korea Tourism Organization (2006, 2007, 2008, 2009), which indicate that more than $65 \%$ of Japanese visitors claim shopping to be one of their primary activities in Korea and one of major features that attracted them to Korea.

Since gifts or souvenirs help remind people of their enjoyable experiences in a tourist destination, they might also be instrumental in causing people to revisit the country. This example likely corresponds better to travel between nearby countries, such as Japan and Korea. Shopping is motivated by a multitude of interests and desires, including people's psychological needs or social desires, in addition to simply owning something unique or something they need (Timothy, 2005). For example, some tourists are prone to window shop to keep abreast with trends in state-of-theart technologies or contemporary fashions. The motivation might result from keeping up with social change or adapting to social norms. The hedonic value of shopping itself 
is inherent tourists enjoying free time on their itinerary. Thus, shopping includes utilitarian motives and values and hedonic motives and values (Timothy, 2005).

An interest in re-visiting a destination for the purpose of shopping may be amplified in the case of short-haul travel between two nations and cheaper prices regardless of relatively high-quality products. As a result, since Japanese tourists' shopping behaviours includes a variety of motivations, satisfaction in shopping appears to be automatically linked to their interest in re-visiting. This finding is similar to those of previous tourist behaviour studies wherein satisfaction is closely associated with intention to act or revisit (Fallon \& Schofield, 2003; Stoel, Wickliffe, \& Lee, 2004).

Second, approximately $96 \%$ of Japanese shoppers who were satisfied and travelled with others showed intention to return to shop in Korea. This indicates that shopping is considered more enjoyable and satisfying when done in the company of other people (i.e. family and friends) rather than alone, as other studies have confirmed (Timothy, 2005). Asian tourists, including Japanese, prefer to travel in groups and share experiences and opinions regarding satisfaction or complaints, compared toWestern tourists, many of whom prefer to travel alone (Heung \& Cheng, 2000; Hobson \& Christensen, 2001; Kim \& Prideaux, 2005). This pattern of socialization is attributed tocultural characteristic of a collective society according to Hofstede's (1997) theory regarding collectivism and individualism of organizational culture. Thus, Japanese group packages should continue to be promoted through associations of like-minded people, such as work groups, student associations or newlywed couples.

Third, satisfied respondents who were accompanied by others indicated a high level of intention to shop with little regard to the amount of money spent. This implies that shopping expenditures may not be constrained by companionship type, satisfaction level, or intention to 
shop to Korea, although other studies indicate that consumers sometimes spend more when their satisfaction levels increase (Heung \& Cheng, 2000; Mak, Tsang, \& Cheung,1999;Wong \& Law, 2003). As already mentioned, the results indicate shopping can be seen as a hedonic activity that involves new industrial products or local indigenous products, and provides opportunities for people to exchange opinions and interact with like-minded people. Since shopping can be fun and pleasurable per se, Japanese tourists are less likely to pay strict heed to budgetary constraints when they purchase souvenirs and gifts. An interesting point related to this is film-induced Japanese tourists, who tend to buy products related to Korean TV celebrities regardless of price (Kim et al., 2007). Thus, the expenditure levels do not appear to be associated with satisfaction level or companionship in a case of Japanese tourists in Korea.

Fourth, this study demonstrates that Japanese tourists preferred shopping venues where product quality is guaranteed over venues with attractive shopping environments. This indicates a Japanese tendency to emphasize practical or purposeful shopping behaviour rather than consumption-based, impulsive behaviour. This is supported by a survey that reported Japanese preferences for Korean food, including kimchi and ginseng, and cosmetics as desirable merchandise (KTO, 2006). Over $71 \%$ of respondents in that study demonstrated a tendency to place more importance on quality merchandise over attractive retail environments. This suggests some interesting practical implications. Sales venues for Japanese tourists are more effective when high-quality shopping items are displayed, even if they are expensive, to draw the visitors inside. This can be an effective and practical marketing tool to stress the quality of the products on offer rather than simply the retail environment.

Fifth, approximately $83.3 \%$ of Japanese tourists who showed an interest in shopping in Korea, preferred malls as shopping venues, and had achieved a high school education or lower 
reported a preference for venues with attractive environments over establishments with highquality products. This finding has important management implications. For example, lesseducated Japanese tourists may be more easily convinced to purchase items through colourful displays, entertainment values, or other environmental factors, thus adhering to what is currently being termed 'shoppertainment' in the retailing and tourism literature (Timothy, 2005) and appears to be connected with impulse recreational purchases (Bloch et al., 1994; Holbrook \& Jackson, 1996; Sargent, 1988).

Sixth, respondents who were university students and indicated an interest in shopping in Korea and preference for shopping malls regarded product quality and cost to be more significant than an enjoyable retail environment in their decisions about where to shop. This may be interpreted as students tending to purchase necessities and lower-priced items, such as accessories and clothing in a shopping mall rather than brand-name products or frivolous items, because they are more likely to face budget constraints. Thus Japanese student shoppers are not as likely to be attracted by a shopping centre with elaborate displays or external appearances in considering where to shop.

Finally, this study concentrated on predicting Japanese shopper intentions to revisit and their shopping preferences by their sociodemographic characteristics and travel-related variables using a CHAID algorithm. The CHAID approach is different from other statistical solutions in that one dependent variable with two or more categories is directly connected to independent variables with two or more categories, forming one tree that most explicitly accounts for relationships among variables. In particular, it is distinct from regression analyses that showcase statistical significance of each independent variable, that is, the magnitude of contribution to explaining dependent variable(s). However, results of the CHAID illustrate the number of 
respondents included in each cell within each category of each independent variable as well as the level of association among one dependent variable and independent variables. This approach helps simplify the interpretation of results and understand them because they are shown in graphic form.

This paper is similar to some previous studies in that they also assessed tourists' preference, intention or behaviour (Chen, 2003; Chung et al., 2004; Diaz-Perez et al., 2005). On the other hand, the results of this study are limited to Japanese shoppers' preferences and intentions, compared to other studies that selected target markets based on outcomes of the CHAID procedure and explored their profiles (Chen, 2003). Thus, because of its underutilized value, future studies would benefit from using this statistical method to link marketing strategies and other tourism contexts.

This study assessed preferences and behavioural characteristics of Japanese tourists, who are well known in the leisure retailing world as big spenders. As noted in previous studies, Japanese shopping behaviour and patterns differ from those of Americans, Europeans and other nationalities (e.g., Keown, 1989; Mak et al., 1999; Reisinger \& Turner, 2002). Thus, there is a need to compare the results of this study to the consumptive behaviours of other national groups. In addition, future studies are needed to compare findings of this study to those of Japanese shopping groups in other destinations outside of Korea. 


\section{REFERNCES}

Ahmed, Z. U., \& Krohn, F. B. (1992). Understanding the unique consumer behavior of Japanese tourists. Journal of Travel and Tourism Marketing, 1(3), 73-86.

Anderson, L., \& Littrell, M. A. (1995). Souvenir-purchase behavior of women tourists. Annals of Tourism Research, 22(2), 328-348.

Asplet, M., \& Cooper, M. (2000). Cultural designs in New Zealand souvenir clothing: The question of authenticity. Tourism Management, 21(3), 307-312.

Bellenger, D. N., \& Korgaonkar, P. K. (1980). Profiling the recreational shopper. Journal of Retailing, 56(3), 77-92.

Bloch, P. H., Ridgway, N. M., \& Dawson, S. A. (1994). The shopping mall as consumer habitat. Journal of Retailing, 70(1), 23-42.

Brasor, P. (2004). Korean wave may help erode discrimination. The Japanese Times. $<$ http://202.221.217.59/print/features/media2004/fd20040627pd.htm> Available from: Accessed 22.03.06.

Butler, R. W. (1991). West Edmonton Mall as a tourist attraction. Canadian Geographer, 35(3), 287-295.

Carmichael, B. A., \& Smith, W. W. (2004). Canadian domestic travel behavior: A market segmentation study of rural shoppers. Journal of Vacation Marketing, 10(4), 333-347.

Chen, J. S. (2003). Market segmentation by tourists' sentiments. Annals of Tourism Research, 30(1), 178-193.

Chung, K. Y., Oh, S. Y., Kim, S. S., \& Han, S. Y. (2004). Three representative market segmentation methodologies for hotel guest room customers. Tourism Management, 25(4), 429-441.

Coles, T. (2004). Tourism and retail transactions: Lessons from the Porsche experience. Journal of Vacation Marketing, 10(4), 378-389.

Diaz-Perez, F. M., Bethencourt-Cejas, M., \& Alvarez-Gonzalez, J. A. (2005). The segmentation of canary island tourism markets by expenditure: Implications for tourism policy. Tourism Management, 26, 961-964.

Fallon, P., \& Schofield, P. (2003). 'Just trying to keep the customer satisfied': A comparison of models used in the measurement of tourist satisfaction. Journal of Quality Assurance in Hospitality and Tourism, 4(3/4), 77-96. 
Finn, A., McQuity, S., \& Rigby, J. (1994). Residents' acceptance and use of a megamulti-mall: West Edmonton Mall evidence. International Journal of Research in Marketing, 11, 127144.

Foderaro, L. W. (18 June 1998). A universal quest for bargains: Japanese flock to outlet center in the HudsonValley. New York Times 15.

Haughton, D., \& Oulabi, S. (1997). Direct marketing modeling with CART and CHAID. Journal of Interactive Marketing, 11(4), 42-53.

Heung, V. C. S., \& Cheng, E. (2000). Assessing tourists' satisfaction with shopping in the Hong Kong special administrative region in China. Journal of Travel Research, 38(4), 396-404.

Heung, V. C. S., \& Qu, H. (1998). Tourism shopping and its contributions to Hong Kong. Tourism Management, 19(4), 383-386.

Hobson, J. S. P. (2000). Tourist shopping in transit: The case of BAAPK. Journal of Vacation Marketing, 6(2), 170-183.

Hobson, J. S. P., \& Christensen, M. (2001). Cultural and structural issues affecting Japanese tourist shopping behaviour. Asia Pacific Journal of Tourism Research, 6(1), 37-45.

Hofstede, G. (1997). Culture's consequences (2nd ed.). Thousand Oaks, CA: Sage.

Holbrook, B., \& Jackson, P. (1996). The social milieux of two North London shopping centres. Geoforum, 27(2), 193-204.

Iverson, T. (1997). Japanese visitors to Guam: Lessons from experience. Journal of Travel and Tourism Marketing, 6(1), 41-54.

Jang, S., Bai, B., Hong, G., \& O’Leary, J. T. (2004). Understanding travel expenditures: A study of Japanese pleasure travellers to the United States by income level. Tourism Management, 25(3), 331-341.

Jansen-Verbeke, M. (1994). The synergism between shopping and tourism: The Japanese experience. In W. F. Theobold (Ed.), Global tourism: The next decade (pp. 347-362). Oxford: Butterworth Heinemann.

Kass, G. V. (1975). Significance testing in automatic interaction detection. Ph.D. thesis, South Africa: University of Weiwaterstrand.

Keown, C. F. (1989). A model of tourists' propensity to buy: The case of Japanese visitors to Hawaii. Journal of Travel Research, 27(3), 31-34. 
Kim, S. S., \& Prideaux, B. (2005). Marketing implications arising from a comparative study of international pleasure tourist motivations, and other travel-related characteristics of visitors to Korea. Tourism Management, 26(3), 347-357.

Kim, S., Agrusa, J., Lee, H., \& Chon, K. (2007). Effects of Korean television dramas on the flow of Japanese tourists. Tourism Management, 28(6), 1340-1353.

Kinley, T. R., Josiam, B. M., \& Kim, Y. (2003). Why and where tourists shop: Motivations of tourist-shoppers and their preferred shopping center attributes. Journal of Shopping Center Research, 10(1), 7-28.

KNTO. (2003). 2003 visitor survey. Seoul: Korea National Tourism Organization.

Ko, T. G. (1999). The issues and implications of escorted shopping tours in a tourist destination region: The case study of Korean package tourists in Australia. Journal of Travel and Tourism Marketing, 8(3), 71-80.

KTO. (2004). 2004 Korea annual statistical report on tourism. Seoul: Korea Tourism Organization.

KTO. (2006). 2006 visitor survey. Seoul: Korea Tourism Organization.

KTO. (2007). 2007 visitor survey. Seoul: Korea Tourism Organization.

KTO. (2008). 2008 visitor survey. Seoul: Korea Tourism Organization.

KTO. (2009). 2009 visitor survey. Seoul: Korea Tourism Organization.

Larke, R. (1994). Japanese retailing. London: Routledge.

Law, R., \& Au, N. (2000). Relationship modeling in tourism shopping: A decision rules induction approach. Tourism Management, 21(3), 241-249.

Leones, J., Colby, B., \& Crandall, K. (1998). Tracking expenditures of the elusive nature tourists of Southeastern Arizona. Journal of Travel Research, 36(Winter), 56-64.

Lesser, J. A., \& Hughes, M. A. (1986). Towards a typology of shoppers. Business Horizons, 29(6), 56-62.

Levin, N., \& Zahav, J. (2001). Segmentation analysis with managerial judgment. Journal of Direct Marketing, 10, 28-47.

Lim, H. (2000). A study of shopping tourists' purchasing decision making. Unpublished thesis, Gyonggi Universit (in Korean).

Littrell, M. A.. (1990). Symbolic significance of textile crafts for tourists. Annals of Tourism Research, 17(2), 228-245. 
Littrell, M. A., Baizerman, S., Kean, R., Gahring, S., Niemeyer, S., Reilly, R., et al. (1994). Souvenirs and tourism styles. Journal of Travel Research, 32(3), 3-11.

Littrell, M. A., Paige, R. C., \& Song, K. (2004). Senior travellers: Tourism activities and shopping behaviours. Journal of Vacation Marketing, 10(4), 348-362.

Magidson, J. (1994). The CHAID approach to segmentation modeling: Chi-square automatic interaction detection. In R. Bagozzi (Ed.), Advanced method of marketing research (pp. 118-159). Cambridge, MA: Blackwell.

Mak, B. L. M., Tsang, N. K. F., \& Cheung, I. C. Y. (1999). Taiwanese tourists' shopping preferences. Journal of Vacation Marketing, 5(2), 190-198.

Mok, C., \& Lam, T. (1997). A model of tourists' shopping propensity: A case of Taiwanese visitors to Hong Kong. Pacific Tourism Review, 1(2), 137-145.

Moscardo, G. (2004). Shopping as a destination attraction: An empirical examination of the role of shopping in tourists' destination choice and experience. Journal of Vacation Marketing, 10(4), 294-307.

Nishiyama, K. (1996). Welcoming the Japanese visitor: Insight, tips, tactics. Honolulu: University of Hawaii Press.

Oh, J. Y., Cheng, C. K., Lehto, X. Y., \& O'Leary, J. (2004). Predictors of tourists' shopping behaviour: Examination of socio-demographic characteristics and trip typologies. Journal of Vacation Marketing, 10(4), 308-319.

Onderwater, L., Richards, G., \& Stam, S. (2000). Why tourists buy textile souvenirs: European evidence. Tourism, Culture and Communication, 2(1), 39-48.

Park, M. K. (2000). Social and cultural factors influencing tourists' souvenir purchasing behaviour: A comparative study on Japanese 'omiyage' and Korean 'sunmul'. Journal of Travel and Tourism Marketing, 9, 81-91.

Park, S., \& Lim, S. (1996). A study of investigating consumers' motivation to shop clothing and preferred outlets. Journal of the Korean Society of Clothing and Textiles, 20(3), 414-428, (in Korean).

Prideaux, B., \& Kim, S. M. (1999). Trends in Korean tourism: The Australian connection. In K. Pookong, \& B. King (Eds.), Asia-Pacific tourism: Regional cooperation, planning and development (pp. 197-209). Melbourne: Hospitality Press.

Reisinger, Y., \& Turner, L. (2000). Japanese tourism satisfaction: Gold Coast versus Hawaii. Journal of Vacation Marketing, 6(4), 299-317. 
Reisinger, Y., \& Turner, L. (2002). The determination of shopping satisfaction of Japanese tourists visiting Hawaii and the Gold Coast compared. Journal of Travel Research, 41, 167-176.

Riquier, C., Luxton, S., \& Sharp, B. (1997). Probabilistic segmentation modeling. Journal of the Market Research Society, 39, 571-587.

Rosenbaum, M. S., \& Spears, D. L. (2005). Who buys that? Who does what? Analysis of crosscultural consumption behaviours among tourists in Hawaii. Journal of Vacation Marketing, 11(3), 235-247.

Rosenbaum, M. S., \& Spears, D. L. (2006). An exploration of spending behaviors among Japanese tourists. Journal of Travel Research, 44, 467-473.

Rowley, J., \& Slack, F. (1999). The retail experience in airport departure lounges: Reaching for timelessness and placelessness. International Marketing Review, 16(4/5), 363-375.

Rufin, R. (2007). Sales growth of Spanish tourist firms: Some implications of Gibrat's Law on marketing management. Tourism Management, 28, 788-805.

Sargent, P. (1988). The leisureplex and the dinosaurs: Developments in shipping and leisure. Leisure Management, 8(5), 20-24.

Snepenger, D. J. (1987). Segmenting the vacation market by novelty-seeking role. Journal of Travel Research, 26(2), 8-14.

Stephenson, R. P., \& Willett, R. P. (1969). Analysis of consumer retail patronage strategies. In P. R. McDonald (Ed.), Marketing involvement in society and the economy (pp. 31-39). Chicago: American Marketing Association.

Stoel, L., Wickliffe, V., \& Lee, K. H. (2004). Attribute beliefs and spending as antecedents to shopping value. Journal of Business Research, 57(10), 1067-1073.

Stone, G. P. (1954). City shoppers and urban identification: Observations on the social psychology of city life. American Journal of Sociology, 60(1), 36-45.

Timothy, D. J. (2005). Shopping tourism, retailing and leisure. Clevedon: Channel View.

Timothy, D. J., \& Butler, R. W. (1995). Cross-border shopping: A North American perspective. Annals of Tourism Research, 22(1), 16-34.

Travel Industry Association of America. (2001). The shopping traveler. Washington, DC: TIA.

Wong, J., \& Law, R. (2003). Difference in shopping satisfaction levels: A study of tourists in Hong Kong. Tourism Management, 24, 401-410. 
Yoon, S. (2000). A study of purchasing behaviour of tourism gifts. Unpublished thesis, Gyonggi University (in Korean). 
Table 1. Respondents' profile and their shopping characteristics

\begin{tabular}{|c|c|c|c|}
\hline Variable & $\%$ & Variables & $\%$ \\
\hline $\begin{array}{l}\text { Gender } \\
\text { Male } \\
\text { Female }\end{array}$ & $\begin{array}{l}32.4 \\
67.6\end{array}$ & $\begin{array}{l}\text { Who you are accompanied by on this tour } \\
\text { Alone } \\
\text { Friends } \\
\text { Association or company } \\
\text { Family or relatives }\end{array}$ & $\begin{array}{r}2.4 \\
53.4 \\
16.9 \\
26.2\end{array}$ \\
\hline $\begin{array}{l}\text { Education level } \\
\text { High school or less } \\
\text { College student } \\
\text { College graduate or above }\end{array}$ & $\begin{array}{r}13.8 \\
9.0 \\
77.2\end{array}$ & $\begin{array}{l}\text { Purpose of this tour } \\
\text { Leisure } \\
\text { Business } \\
\text { Visit to friends or relatives } \\
\text { Only shopping } \\
\end{array}$ & $\begin{array}{r}76.6 \\
4.5 \\
3.8 \\
11.4\end{array}$ \\
\hline $\begin{array}{l}\text { Age } \\
20 \text { or less } \\
21-30 \\
31-40 \\
41-50 \\
51 \text { or older }\end{array}$ & $\begin{array}{r}2.8 \\
29.3 \\
35.2 \\
19.7 \\
13.1\end{array}$ & $\begin{array}{l}\text { Main shopping information sources } \\
\text { Acquaintances } \\
\text { Travel agency } \\
\text { Tourism information guidebook } \\
\text { Internet } \\
\text { TV, radio } \\
\text { Hotel, airline }\end{array}$ & $\begin{array}{r}18.3 \\
9.7 \\
48.3 \\
17.9 \\
3.4 \\
1.0\end{array}$ \\
\hline $\begin{array}{l}\text { Occupation } \\
\text { Company employee } \\
\text { Own business } \\
\text { Sales/service } \\
\text { Student } \\
\text { Housewife } \\
\text { No job } \\
\text { Other }\end{array}$ & $\begin{array}{r}48.3 \\
4.1 \\
5.9 \\
7.6 \\
27.9 \\
1.4 \\
2.1\end{array}$ & $\begin{array}{l}\text { Perceived inconvenience in shopping } \\
\text { Transportation } \\
\text { Language barrier } \\
\text { Forced buying } \\
\text { Unkindness } \\
\text { Safety problem } \\
\text { Exchange of foreign currency } \\
\text { Guide or guiding map or signboard } \\
\text { No problem }\end{array}$ & $\begin{array}{r}21.0 \\
37.5 \\
9.3 \\
2.9 \\
1.2 \\
3.7 \\
9.7 \\
6.7\end{array}$ \\
\hline $\begin{array}{l}\text { Monthly household income } \\
200,000 \text { yen or below } \\
200,001-300,000 \text { yen } \\
300,001-400,000 \text { yen } \\
400,001-500,000 \text { yen } \\
500,001 \text { or more }\end{array}$ & $\begin{array}{l}23.7 \\
18.8 \\
19.5 \\
26.2 \\
11.3\end{array}$ & $\begin{array}{l}\text { Shopping spending } \\
20,000 \text { yen or below } \\
20,001-40,000 \text { yen } \\
40,001-60,000 \text { yen } \\
60,000 \text { yen or more }\end{array}$ & $\begin{array}{l}30.9 \\
21.3 \\
28.6 \\
18.9\end{array}$ \\
\hline $\begin{array}{l}\text { Frequency of visits to Korea } \\
1 \\
2-4 \\
5 \text { or more }\end{array}$ & $\begin{array}{r}52.4 \\
38.6 \\
9.0\end{array}$ & $\begin{array}{l}\text { The product which you most want to buy } \\
\text { Clothes } \\
\text { Food } \\
\text { Duty free products of foreign brands }\end{array}$ & $\begin{array}{l}11.7 \\
71.4 \\
16.9\end{array}$ \\
\hline $\begin{array}{l}\text { Duration of this tour } \\
1 \text { night } \\
2 \text { nights } \\
3 \text { nights } \\
4 \text { nights } \\
5 \text { nights or more }\end{array}$ & $\begin{array}{r}0.3 \\
39.7 \\
36.6 \\
20.3 \\
3.1\end{array}$ & $\begin{array}{l}\text { Preferred shopping place } \\
\text { Duty free shop } \\
\text { Shopping mall } \\
\text { Department } \\
\text { Gift sale shop } \\
\text { Traditional market }\end{array}$ & $\begin{array}{r}20.7 \\
19.3 \\
4.5 \\
3.8 \\
51.7\end{array}$ \\
\hline
\end{tabular}


Figure 1. Conceptualization of the study
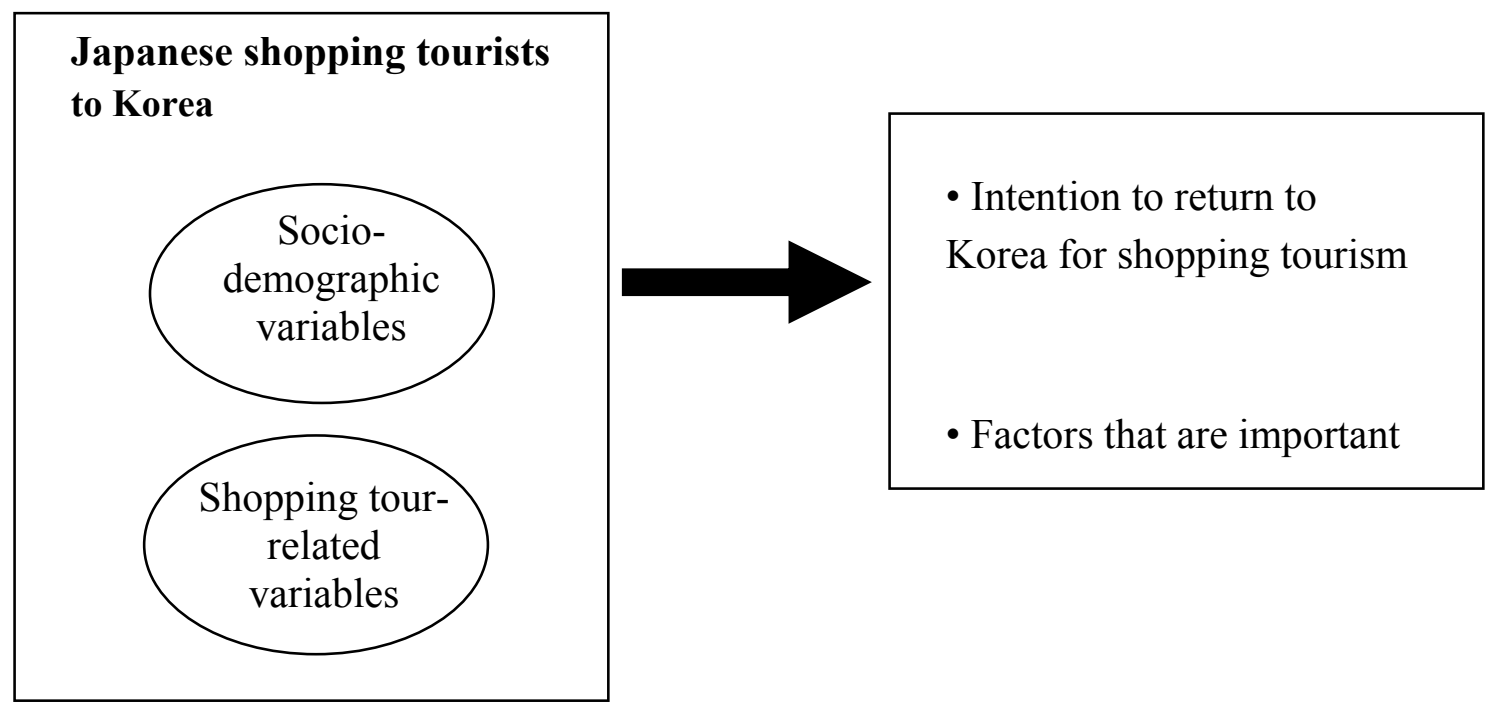
Figure 2. Map of shopping districts

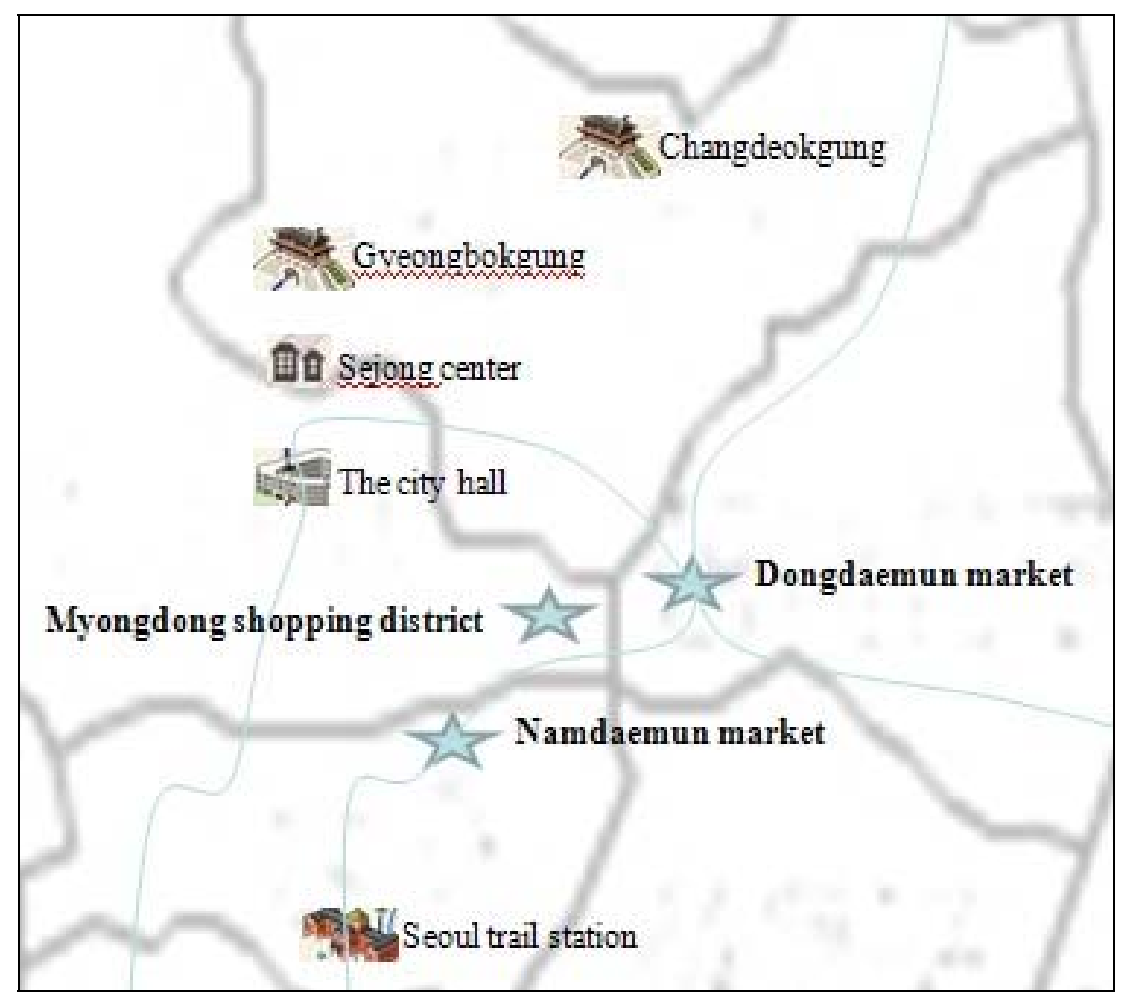


Figure 3. Results of identifying intention to return to Korea for shopping tourism

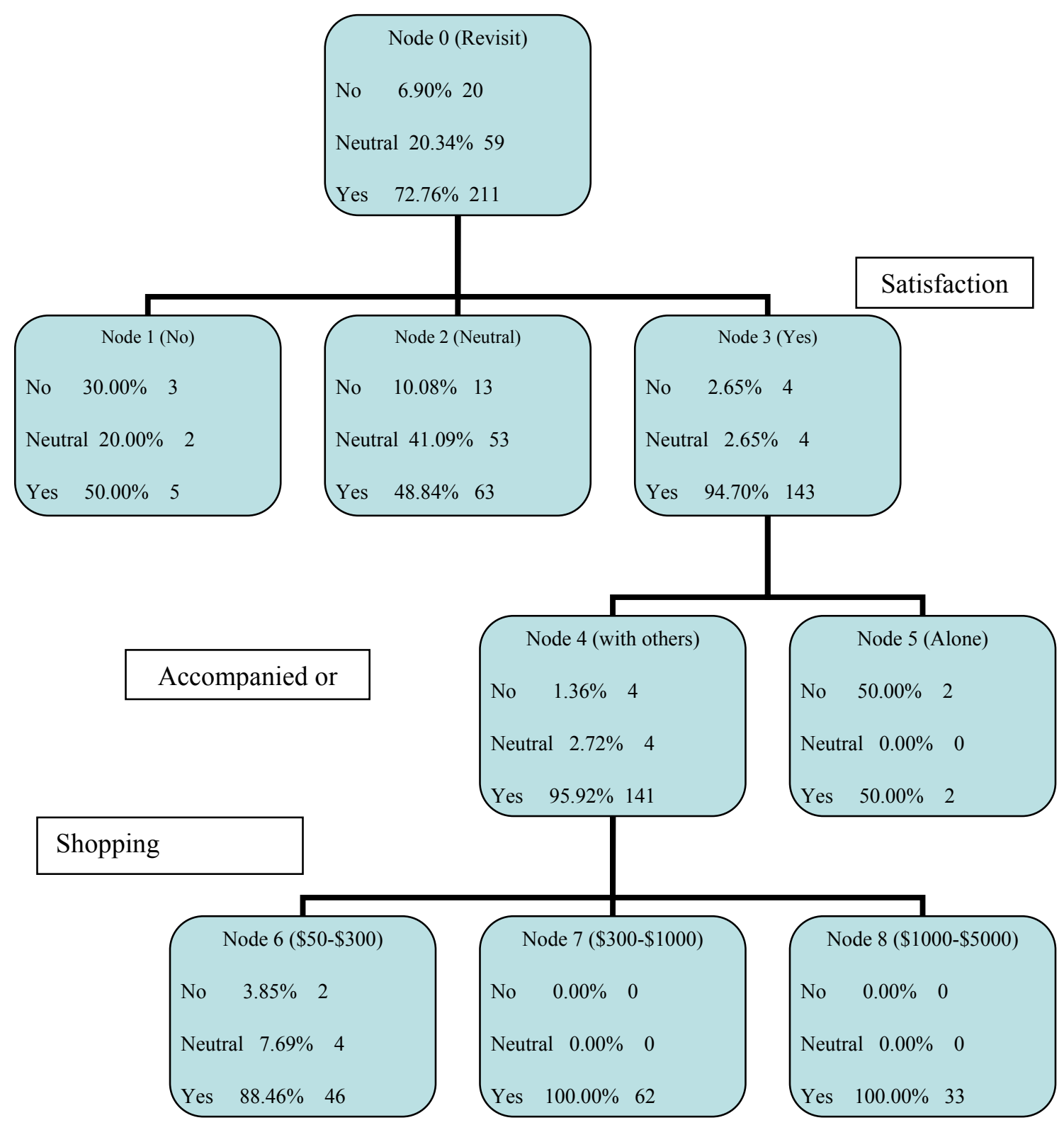


Figure 4. Risk chart identifying intention to return to Korea for shopping tourism

\begin{tabular}{c|c|c|c|c|c}
\hline \multicolumn{2}{c|}{} & \multicolumn{6}{c}{ Misclassification Matrix } \\
\cline { 2 - 7 } \multicolumn{2}{c}{} & No & Neutral & Yes & Total \\
\hline \multirow{3}{*}{ Predicted Category } & No & 2 & 0 & 2 & 4 \\
\cline { 2 - 7 } & Neutral & 0 & 0 & 0 & 0 \\
\cline { 2 - 7 } & Yes & 18 & 59 & 209 & 286 \\
\cline { 2 - 6 } & Total & 20 & 59 & 211 & 290 \\
\hline \multicolumn{2}{c}{ Risk Estimate } & \multicolumn{7}{c}{0.272414} \\
\hline \multicolumn{2}{c}{ SE of Risk Estimate } & \multicolumn{7}{c}{0.0261431} \\
\hline
\end{tabular}


Figure 5. Gain chart of those who intended to return to Korea for shopping tourism

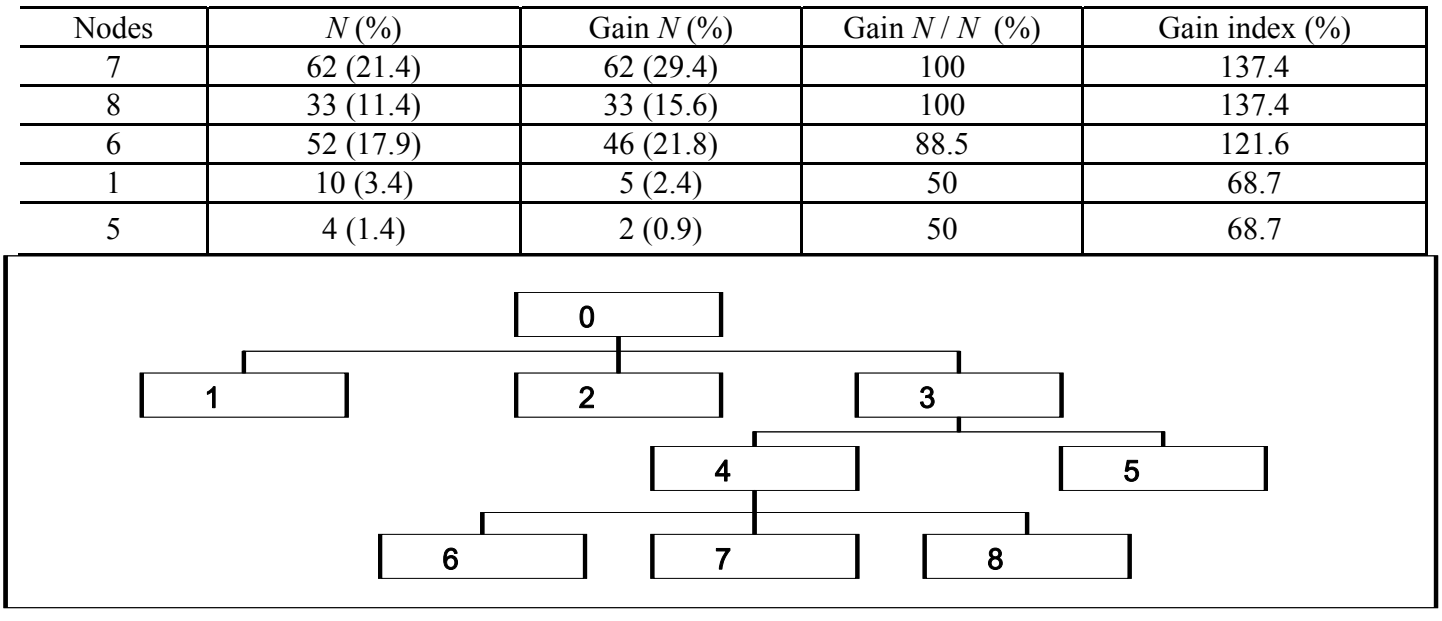


Figure 6. Results of identifying factors that are considered important by tourists when deciding where to shop in Korea

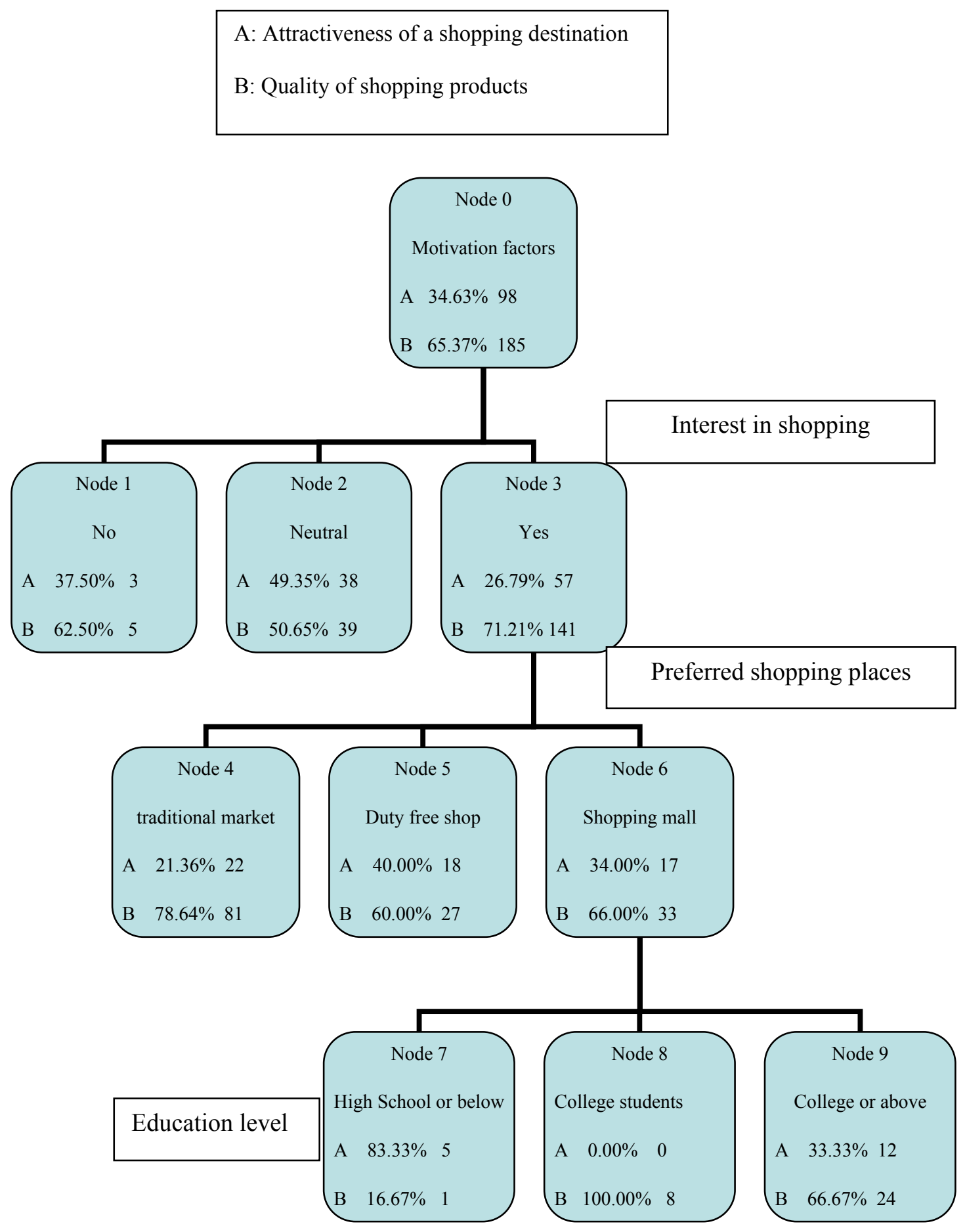


Figure 7. Risk chart identifying factors which are considered important by tourists when deciding where to shop in Korea 
Figure 8. Gain chart of respondents who considered "quality of shopping products" as being more important than "attractiveness of a tourism destination"

\begin{tabular}{c|c|c|c|c|}
\hline Nodes & $N(\%)$ & Gain $N(\%)$ & Gain $N / N(\%)$ & Gain index (\%) \\
\hline 8 & $8(2.8)$ & $8(4.3)$ & 100 & 153 \\
\hline 9 & $36(12.7)$ & $24(13.0)$ & 66.7 & 102 \\
\hline 1 & $8(2.8)$ & $5(2.7)$ & 62.5 & 95.6 \\
\hline 2 & $77(27.2)$ & $39(21.1)$ & 50.6 & 77.5 \\
\hline 7 & $6(2.1)$ & $1(0.5)$ & 16.7 & 25.5 \\
\hline
\end{tabular}

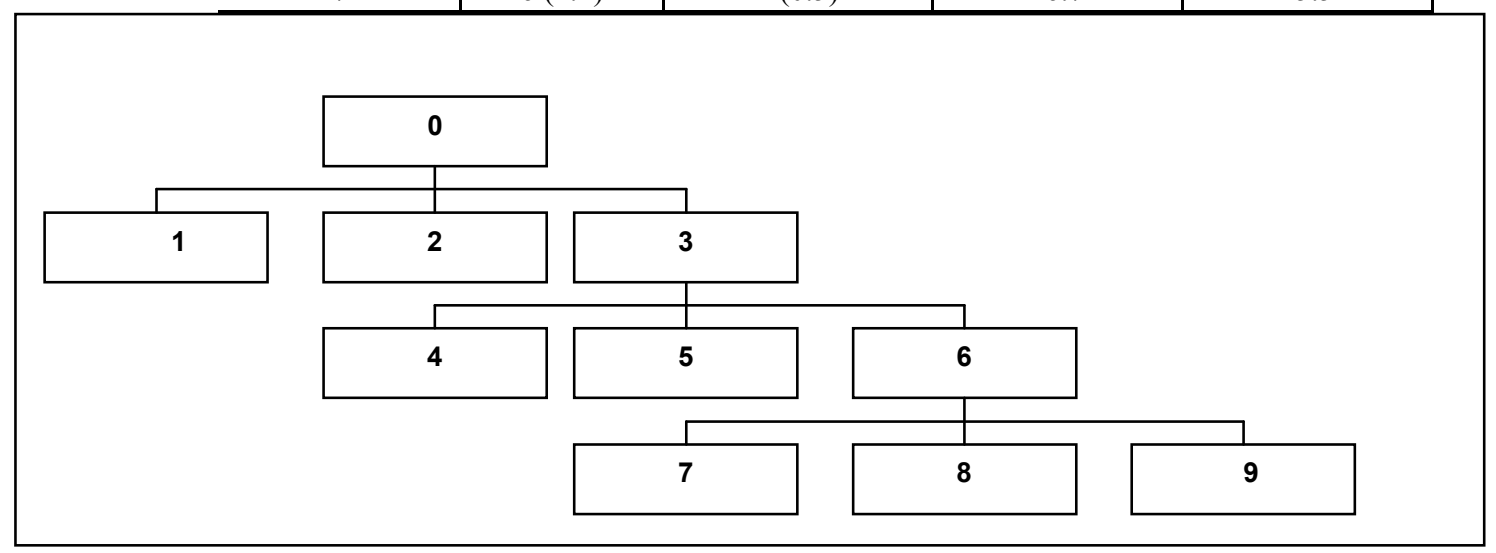

